\title{
RISTO RINNE
}

\section{Pohjolan aikuiskasvatustutkijoille vuosikirja}

Aikuiskasvatuksella on Pohjoismaissa pitkät perinteet. Kansan valistaminen on suurista joukkoliikkeistä lähtien luonut pohjoismaisen demokratian sivistyksellistä perustaa. Alan tutkimustakin harjoitetaan nykyään viljalti Ruotsissa ja Suomessa, hieman vähemmän viljalti Norjassa ja Tanskassa. Alan tutkijoiden toisesta pohjoismaisesta kokouksestaan Ruotsista tekemä ensimmäinen vuosikirja ei tunnista islantilaista tai färsaarelaista aikuiskasvatustutkimusta.

Suomeen saatiin Pohjoismaiden, Aulis Alasen epäilyn mukaan peräti Euroopan, ensimmäinen aikuiskasvatuksen professuuri Yhteiskunnallisen korkeakoulun valveutumisen myötä vuonna 1946. Toinen professuuri perustettiin maahan vuonna 1980, ja suunnitteilla on uusia. Tanskan ainokainen professuuri pystytettiin vuonna 1969, ja Ruotsi sai ainokaisensa 1982. Norjassa kummastellaan vieläkin, onko ala oma itsenäinen oppiaineensa, vaikka sosiologi Odd Nordbaug alueelta väittelikin. Aikuiskasvatuksen väitöskirjoja ja muuta tutkimusta on tehty eniten Ruotsissa. Suomi seuraa kakkosena.

Pohjoismaiden tutkijoiden ensimmäinen vuosikirja "Social Change and Adult Education Research" on Linköpingissä tehty komeakantinen konferenssiraportti, jonka ulkokuori ja nimi lupaavat paljon. Raporttiin on kerätty peräti 24 artikkelia lähinnä Göteborgin 46 tutkijan kokouksesta. Kirja alkaa Jukka Tuomiston lyhyellä historiallisella juonnolla ja jatkuu kutakin neljää maata käsittelevällä yleisesityksellä. Tämän jälkeen seuraa neljä esitystä Tanskasta, kuusi Suomesta ja viisi kumpaisestakin, Norjasta ja Ruotsista. Sivuja teokseen on kertynyt kaksi ja puoli sataa.
Social Change and Adult

Education Research - Adult

Education Research in Nordic

Countries 1990/91. Linköping

1992. Department of Education and Psychology, University of Linköping.

Maiden yleisesityksissä on pyritty noudattamaan jonkinkaltaisen vertailtavuuden mahdollistavaa yhtenäistä kaavaa. Ensin selostetaan maan aikuiskasvatuksen tutkimuksen historiaa, sitten rakennetta, organisaatiota, verkostoa, rahoitusta ja tutkimusalueita. Poikkeuksen tekee kuitenkin kirjastotieteilijä Maj Klasson Ruotsin aikuiskasvatustutkimuksen keskuspaikasta, Linköpingistä. Hän ei tyydy vain esittelemään tilannetta yleisellä tasolla, vaan yrittää tutkia tutkimuksen laajenemista Ruotsissa "aikuiskoulutuksen sosiaalisen ja kognitiivisen institutionalisoitumisen" viitekehikosta empiirisen aineiston avulla.

Kokonaisuudessaan artikkelien taso on hyvin kirjava. Vaikka niitä ei voitaisikaan katsoa pohjoismaisen tutkimuksen edustavaksi näytöksi, mikä juonnossa kielletään, on mukana luvattomankin heikkoja ja luonnosmaisia reunamerkintöjä. Jos kirjaa tarkastelisi pohjoismaisen aikuiskasvatustutkimuksen kattavana indikaattorina, ei taso kaikin osin kummoinen ole.

Toisaalta välissä on myös kohtuullista tavaraa ja tunnettujakin nimiä Kjell Rubensonista ja 
Staffan Larsonista Knud Illerikseen saakka. Linköpingissä näyttää olevan huudossa tarkastella tiedon ja uusien yhteiskunnallisten liikkeiden välisiä suhteita. Illeris taas pysyttäytyy vanhassa tutussa tanskalaisessa kvalifikaatiodiskurssissa korostaen nyt eritoten "henkilökohtaisten kvaliteettien" problematiikkaa. Kaikkineen suomalaisten esitykset eivät kalpene pohjoismaisessa perheessä, jos eivät mitenkään häikäisekään.

Useammassa artikkelissa nähdään aikuiskasvatuksen tutkimuksen suuntautumisen tapahtuneen melko tavalla koulutuspoliittisten reformihankkeiden kytköksissä. Myös yksilöpainotteisuus nähdään joissakin artikkeleissa häiritsevänä piirteenä. Juonnossa katsotaan, että erityyppiset kyselylomaketutkimukset ovat saaneet viime vuosina antaa tilaa kehittämishankkeille ja toimintatutkimuksen muodikkaille lähtökohdille.

Konferenssiraportin lukijaa häiritsee artikkelien eritasoisuus ja hajanaisuus. Lukuisat hätäisyyttä ilmentävät kirjoitusvirheet eivät yhtään paranna kuvaa.

Myöskään vaativa lupaus tarkastella aikuiskasvatustutkimusta suhteessa sosiaaliseen muutoksen ei toteudu, vaikka joissakin artikkeleissa tähän suuntaan kuljetaankin. Vika on toki yleisempikin tämäntyyppisissä koosteissa, mutta ilmeinen etu vuosikirjan jatkotoimittajille olisi silti keskittyminen tiettyihin teemoihin. Ei ole myöskään järkeä siinä, että minkä tahansa tasoinen tarina läpäisee seulan. Jatkossa on vain hyväksi harjoittaa jonkinkaltaista karsintaa.

Yhdenkaltaisessa päättöartikkelissa Staffan Larsson on haastatellut 124 aikuiskouluttajaa ja etsinyt eroja nuorten ja aikuisten opettamisen välillä. Vallitsevin käsitys kouluttajien parissa on, että opiskelevat aikuiset ovat nuoria enemmän vakavissaan, enemmän motivoituneita ja vaativat opetukseltaan tehokkuutta. Kiristyvän tuloksellisuuden oloissa ja aikuisten alkaessa vallata keski- ja korkea-asteenkin oppilaitoksia on syytä ottaa seikka vakavasti. Aikuiset ovat työtä ja elämää nähtyään tosissaan, eivätkä enää tyydy elämästä irralliseen koulumaiseen aikansa tuhlaamiseen. Aikuiskoulutuksen on kyettävä tarjoamaan investoinnin arvoinen vaihtoehto muun maailman pauhulle.

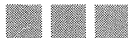

Rosoisuudesta piittaamatta on toki tervehdittävä ilolla Pohjolan aikuistutkijoiden vuosikirjan synnytystuskia. Näinhän tiede usein käy kansainvälisesti jaloilleen. Suunnitteilla on jo vuosikirjan jatkotyö ja vakinaistaminen. Myös Pohjolaa laajempi eurooppalainen tutkijayhteistyö on etenemässä. Tämä kaikki lisää suomalaisten mahdollisuuksia kirjoittaa ja osallistua myös tulevalla Euroopan Yhteisön kotikielellään. Puutetta ovat ainakin jotkut Suomessa kokeneet sen jälkeen, kun Adult Education in Finland mahtikäskyllä lakkautettiin ja useamman ministeriön toimin alettiin rahoittaa paremmin Suomen kasvojen kohottajaksi soveltuvaa LEIF:iä. 